\title{
Nasopharyngeal Cancer pN3 TNM Finding v6
}

National Cancer Institute

\section{Source}

National Cancer Institute. Nasopharyngeal Cancer pN3 TNM Finding v6. NCI Thesaurus. Code C64477.

Nasopharyngeal cancer with metastasis to one or more lymph nodes greater than $6 \mathrm{~cm}$ and/or to lymph nodes which are whole or in part in the supraclavicular fossa. (from AJCC 6th Ed.) 